\title{
İlkokul 4. Sınıf Öğrencilerinin Doğru ve Akıcı Sessiz Sözcük Okuma Düzeyinin Öğrencilerin Okuduğunu Anlama Becerisi ve Okuma Motivasyonu ile İlişkisi
}

\author{
Seda SARAÇLI ÇELIKK \\ Aydın Adnan Menderes Üniversitesi \\ sedasaracli@windowslive.com \\ https://orcid.org/0000-0001-9140-5342 \\ Nuri KARASAKALOĞLU \\ Aydın Adnan Menderes Üniversitesin \\ nkarasaloglu@adu.edu.tr \\ https://orcid.org/0000-0002-5577-4551
}

Araştırma Makalesi

Geliş Tarihi: 23.10.2020

Revize Tarihi: 26.06.2021

DOI: $10.31592 /$ aeusbed.814589

Kabul Tarihi: 01.07.2021

\section{Atıf Bilgisi}

Saraçlı Çelik, S. ve Karasakaloğlu, N. (2021). ilkokul 4. sınıf öğrencilerinin doğru ve akıcı sessiz sözcük okuma düzeyinin öğrencilerin okuduğunu anlama becerisi ve okuma motivasyonu ile ilişkisi. Ahi Evran Üniversitesi Sosyal Bilimler Enstitüsü Dergisi, 7(2), 467-484.

\section{ÖZ}

Bu çalışmanın amacı; 4. sınıf öğrencilerinin doğru ve akıcı sessiz sözcük okuma düzeyinin, öğrencilerin okuduğunu anlama becerileri ve okuma motivasyonları ile ilişkisini belirlemektir. Araştırma örneklemini 2016-2017 eğitim öğretim yılında İzmir Buca ilçesinde bulunan devlet okullarında dördüncü sınıfa devam eden 725 öğrenci oluşturmaktadır. Araştırmada nicel araştırma modeli kullanılmıştır. Veri toplama aracı olarak Doğru ve Akıcı Sessiz Okuma Testi” (DASSOT), Okuduğunu Anlama Testi, Okuma Motivasyonu Ölçeği kullanılmıştır. Araştırma sonucunda elde edilen veriler istatistik paket programı ile değerlendirilerek, öğrencilerin doğru ve akıcı sessiz sözcük okuma düzeyinin, öğrencilerin okuduğunu anlama becerileri ve okuma motivasyonları ile anlamlı bir ilişkisinin olup olmadığı incelenmiştir. Araştırma sonucunda öğrencilerin doğru ve akıcı sözcük okuma düzeyleri ile okuduğunu anlama becerileri ve okuma motivasyonları arasında istatistiksel açıdan anlamlı bir ilişki bulunduğu saptanmıştır. Öğrencilerin doğru ve akıcı sessiz sözcük okuma düzeylerinde öğrencilerin Türkçe dersi not ortalamaları, cinsiyetleri, evde kitaplık, internet ve kendine ait odalarının olması, anne-baba eğitim düzeyleri, anne-baba meslekleri arasında anlamı farklılıkların olduğu sonucuna ulaşılmıştır. Sonuçlar okuma motivasyonu ve okuduğunu anlama becerisi düzeyi yüksek olan öğrencilerin doğru ve akıcı sessiz sözcük okuma düzeylerinin de yüksek olduğunu göstermiştir.

Anahtar Kelimeler: Okuma, okuduğunu anlama, akıcı okuma, sessiz okuma, sessiz okuma akıcıllğı, okuma motivasyonu.

\section{Correlation Between 4th Grade Primary School Students' Level of Correct and Fluent Silence Word Reading and Reading Comprehension Skills and Reading Motivation}

\begin{abstract}
The aim of this study is to determine the relationship between 4th grade primary school students' level of correct and fluent silence word reading and their reading comprehension skills and reading motivation. The research sample consists of 725 students attending the fourth grade in the public schools in the 2016-2017 academic year in Izmir, Buca. Quantitative research model was used in the research. Accurate and Fluent Silent Reading Test (DASSOT), Reading Comprehension Test and Reading Motivation Scale were used as data collection tools. The data obtained from the study were analyzed through SPSS program and whether the students 'level of reading the correct and fluent words of silence has a meaningful relationship with the students' reading comprehension skills and reading motivations was investigated. As a result of the study, it was found that there is a statistically significant relationship between the correct and fluent word reading levels of the students and their reading comprehension skills and reading motivations. It was seen that there are significant differences according to students' Turkish lesson grade averages, their genders, their having library-internet and self-owned rooms at their homes, parent education levels and parent professions variables in their levels of correct and fluent silence word reading.
\end{abstract}

Keywords: Reading, reading comprehension, fluent reading, silent reading, silent reading fluency, reading motivation 


\section{Giriş}

Türkçe öğretimi dinleme, konuşma, okuma ve yazma becerileri esas alınarak yapılandırılmıştır. Bu beceriler içerisinde okuma becerisi ve okuma becerisinin önemi geçmişten beri süregelen aynı zamanda önemini hiç kaybetmeyen bir konu olmuştur. Okumanın ilkokul çağıyla birlikte öğrenilmesi insan hayatında gerek akademik gerek sosyal anlamda birçok gelişime ve değişime sebep olmaktadır.

Okuma becerisinin türleri günümüze kadar birçok farklı şekillerde ele alınmıştır. Güneş (2007) okuma türlerini "okuma hedefine (eğlenmek, bilgilenmek vb.), kullanılan metoda (sesli, yarı sesli, sessiz okuma vb.), metin çeşidine (seçmeli okuma, tam okuma vb.), faydalanılan gereçlere (kitaptan, ekrandan okuma vb.), göz faaliyetlerine (dik, çapraz, zikzak okuma vb.) ve bireylere göre (bağımsız okuma, paylaşarak okuma birlikte okuma vb.)" (s. 127) olarak sınıflandırırken Ertuğrul'da (2015) okuma çeşitlerini sesli ve sessiz okuma olmak üzere iki başlık adı altında incelemiştir.

Bireylerin en çok zaman ayırdıkları okuma yöntemlerinden biri sessiz okumadır. Sessiz okuma daha hızlı okumayı sağlamakta ve bununla birlikte anlamayı da olumlu anlamda etkilemektedir. Sessiz okuma akıcılığı öğrencilerin, öğrenmesini ve zihinsel yapısını geliştirmesini kolaylaştırmaktadır. Çelik (2006) sesli okumadan sessiz okumaya geçiş sürecini; okuma yazma becerisinin tamamen edinilmesi ile sesli okuma uygulamalarından yola çıkarak ikinci sınıfa yaklaşırken sessiz okuma alışkanlığı oluşturulmaya başlandığını ve bu süreçten sonra sessiz okuma etkinliklerinin yapılması şeklinde ifade etmiştir.

Aytaş 'a (2005) göre ise sessiz okuma en çok kullanılan okuma türü olup, öğrencinin bireysel olarak öğrenmesinde, verimli zaman geçirilmesine faydası ve her ortamda kullanılabilen okuma çeşidi olması bakımından faydalıdır. Karakuş ve Taş'a (2007) göre sessiz okuma, "okuma akıcılığı sağlamak ve hız kazandırmak için kullanılmaktadır." (s. 25). Okuma öğrenildikten sonra üzerinde durulan en önemli konular okuduğunu anlama ve akıcı okumadır. Akıcı okuma, okuma düzeyinin belli bir aşamaya gelmesidir. Araştırmalar akıcı okuyan ve okuduğunu anlayan öğrencilerin sadece Türkçe dersinde değil diğer derslerde de başarılı olduklarını göstermektedir (Ateş, 2008; Çetinkaya, Ülper ve Yağmur, 2015; Y1ldız, 2013; Y1lmaz, 2011).

Kuhn, Schwanenflugel ve Meisinger (2010) akıc1 okumayı, okumanın değerlendirilmesinde itici bir güç ve eğitimciler, araştırmacılar için ise bir yol gösterici olarak görmektedirler. Akıcılıkla ilgili yapılan çoğu değerlendirmenin doğru olmadığını, akıc1lı̆̆1 daha doğru değerlendirebilmek için öncelikle doğruluk, otomatiklik ve prozodinin anlaşılmasının gerektiğini savunmaktadırlar. Yaptıkları çalışmada kelime tanıma yerine akıcılık değerlendirmelerindeki doğruluğa önem vererek, akıcılığa karşı bakış açısını daha farklı yönlere taşımayı hedeflemişleridir. Bunu yanı sıra akıcı okumayı sesli okumada basitçe kelime teşhisi, elverişli sürat, üslup ve ezgiler ile kendini gösteren, sesli ve sessiz okumada anlamayı etkileyen önemli bir etmen olarak ifade etmişlerdir.

Okumada anlama ise sesli ya da sessiz okunan metni anlamaktan daha fazlasıdır. Sadece sosyal hayatta bile önemi büyüktür. Okuduğunu anlama birden fazla beceri ve kabiliyetin bir araya gelmesinden oluşan bir vazifedir (Oakhill, Cain ve Elbro, 2014). Okuyucu okuduklarını zihinsel bir yorumlamanın ardından kavramaya çalışır. Daha sonra bu zihinsel süreçlerin sonunda anlama gerçekleşir. Anlama becerilerinin geliştirilmesinin en önemli yolu okumaktan geçmektedir.

Ülper'e (2014) göre araştırmacılar daha çok öğrencilerin okuma problemleri ve güçlüklerini ortadan kaldırmaya yönelik okuma yöntemleri üzerine çalışmalar yaparak, öğrencilerin okuma düzeylerini iyileştirme durumlarını incelemişlerdir. Bu araştırmaların öğrencilerin okuma becerilerinin geliştirilmesinde kullanılabilecek yöntem ve stratejilerin ehemmiyetini ortaya çıkardığı konusu şüphesizdir. Fakat etkisi araştırılan yöntemlerin kullanılması ancak uygulanmalarına bağlıdır. Bunun için öncelikle öğrencilerin okuma yapmaları gerekmektedir. Dolayısıyla ilk olarak öğrencilerin okumaya meyilli olma durumları nedir ya da öğrencilerde okumaya karşı nasıl istek oluşturulabilir suallerine cevap bulunarak sürece başlamak gerekmektedir. 
Gambrell (2011) okuma motivasyonu ve okuma becerisi ilişkisini "Okumak için motivasyonu olan öğrenciler okuma yapar, okumaya zaman ayırır ve okuma alışkanlığı kazanırlar.” (s. 5) şeklinde ifade etmiştir. Bunun için öğrencinin hem içsel hem de dışsal olarak okumaya karşı motivasyonunun sağlanması bireyin yaşamında hayati önem taşıyan okumanın sürekliliğini sağlayacaktır. Dolayısıyla doğru ve akıcı okuma becerilerinin geliştirilmesinin temeli öncelikle okuma motivasyonun düzeyi ile yakından ilişkilidir.

Öğretmenler öğrenciler okumayı öğrendikten sonra öğrencilerin, doğru ve akıcı șekilde anlayarak okuyabilmeleri konusuna eğilmektedirler. Doğru, akıcı ve anlayarak okuyan öğrenciler hem anlama hem de anlatma dil becerilerini iyi kullanabilmekte ve bu becerileri geliştirebilmektedir. Okumaya meyili olan ve okuyan, okuduğunu pratik bir şekilde yorumlayarak okuduklarından çıkarımlar yapan kişiler yetiştirmek eğitim öğretimin amaçlarındandır.

Bu bağlamda sessiz okuma türünün sesli okuma türüne oranla daha fazla kullanılan bir okuma çeşidi olması, ölçme değerlendirme çalışmalarında sessiz okuma akıcılığına sesli okuma akıcılığına göre daha az rastlanması, alanda yapılan çalışmalara farklı bulgularla yön vermesi, konu hakkında öğretmenlerin daha fazla bilgi sahibi olmaları, sessiz okuma akıcıllı̆ı konusunda hem değerlendirme hem de okuduğunu anlama ve okuma motivasyonu arasındaki ilişkiden yola çıkılarak çalışmalarını daha olumlu yönde şekillendirmelerine katkı sağlamak maksadıyla bu araştırmada ilkokul dördüncü sınıf öğrencilerinin doğru ve akıcı sessiz sözcük okuma düzeyinin, okuduğunu anlama becerisi ve okuma motivasyonu ile ilişkisi irdelenmiştir.

Araştırmanın esas amacı İlkokul 4. Sınıf öğrencilerinin doğru ve akıcı sessiz sözcük okuma düzeyinin, okuduğunu anlama becerisi ve okuma motivasyonları ile ilişkisini ortaya çıkarmaktır. $\mathrm{Bu}$ hedef doğrultusunda aşağıdaki alt problemlere cevap verilmeye çalışılmıştır.

1. Öğrencilerin doğru ve akıcı sessiz sözcük okuma sonuçları nelerdir?

2. Öğrencilerin okuduğunu anlama testi sonuçları nelerdir?

3. Öğrencilerin okuma motivasyonu testi sonuçları nelerdir?

4. İlkokul 4. Sınıf öğrencilerinin doğru ve akıcı sessiz sözcük okuma düzeyiyle okuduğunu anlama becerileri arasında ilişki var mıdır?

5. İlkokul 4. Sınıf öğrencilerinin doğru ve akıcı sessiz sözcük okuma düzeyiyle okuma motivasyonları arasında ilişki var mıdır?

6. İlkokul 4. Sınıf öğrencilerinin doğru ve akıcı sessiz sözcük okuma düzeyiyle Türkçe ders notu ortalamaları arasında ilişki var mıdır?

7. Cinsiyete göre öğrencilerin doğru ve akıcı sessiz sözcük okuma düzeylerinde anlamlı farklılık var midir?

8. Öğrencilerin evlerinde internet olması durumuna göre doğru ve akıcı sessiz sözcük okuma düzeylerinde anlamlı farklılık var midır?

9. Öğrencilerin evinde kendine ait odası olup olmaması durumuna göre doğru ve akıcı sessiz sözcük okuma düzeylerinde anlamlı farklılık var mıdır?

10. Öğrencilerin evinde kitaplık olup olmaması durumuna göre doğru ve akıcı sessiz sözcük okuma düzeylerinde anlamlı bir farklılık var mıdır?

11. Anne eğitim düzeyine göre öğrencilerin doğru ve akıcı sessiz sözcük okuma düzeylerinde anlamlı farklilik var midir?

12. Baba eğitim düzeyine göre öğrencilerin doğru ve akıcı sessiz sözcük okuma düzeylerinde anlamlı farklılık var midir?

13. Anne mesleğine göre öğrencilerin doğru ve akıcı sessiz sözcük okuma düzeylerinde anlamlı farklılık var midır?

14. Baba mesleğine göre öğrencilerin doğru ve akıcı sessiz sözcük okuma düzeylerinde anlamlı farklılık var midır? 


\section{Yöntem}

Yöntem kısmında; çalışma modeli, evren ve örneklem, verilerin toplanması ve analizi konularında bilgiler mevcuttur.

\section{Çalışma Modeli/Deseni}

Bu çalışma ile İzmir ili Buca ilçesindeki devlet okullarında 2016-2017 eğitim yılında ilkokul dördüncü sınıf öğrencilerinin doğru ve akıcı sessiz sözcük okuma düzeyinin, öğrencilerin okuduğunu anlama becerisi ve okuma motivasyonları ile ilişkisinin incelenmesi amaçlanmıştır. Çalışmada ilişkisel tarama modelinden yararlanılmıştır. İlişkisel tarama modelleri iki ya da daha fazla değişken arasında birlikte değişim varlığını ve derecesini belirlemeye yönelik çalışmalarda kullanılmaktadır (Karasar, 2011).

\section{Evren ve Örneklem}

Araştırmanın evreni, İzmir ilinin Buca ilçesindeki devlet okullarında eğitim gören ilkokul dördüncü sınıf öğrencileridir. Araştırmanın örneklemi için İzmir Buca ilçesindeki 34 ilkokula gidilmiştir. Rastlantısal örnekleme yoluyla her okuldan bir tane 4. sınıf seçilerek çalışma grubu 725 öğrenci olarak oluş̧urulmuştur.

Tablo 1

Öğrencilerin Cinsiyet Dă̆glımı

\begin{tabular}{lcc}
\hline Cinsiyet & f & \% \\
\hline Kiz & 362 & 49.93 \\
Erkek & 363 & 50.07 \\
Toplam & 725 & 100 \\
\hline
\end{tabular}

\section{Veri Toplama Araçları}

Araştırma verileri öğrencilerin okuduğunu anlama düzeyini ortaya çıkarmak için Okuduğunu Anlama Testi (Yıldız, 2010), öğrencilerin okuma motivasyonları durumu için Okuma Motivasyonu Ölçeği (Yıldız, 2010), akıcı sessiz sözcük okuma becerilerinin ölçümü amacıyla Ülper ve Yağmur iş birliğiyle hazırlanan Doğru ve Akıcı Sessiz Sözcük Okuma Testi (DASSOT) uygulanmıştır.

Araştırmada uygulanan testler ayrı ayrı değerlendirilmiştir. Okuduğunu Anlama Başarı Testi için doğru yanıtlara 1'er, hatalı yanıtlara ise 0 puan verilecek şekilde düzenlenmiştir. Okuduğunu Anlama Başarı Testi sonucuna göre en az 0 puan alınabilirken en fazla alınabilecek puan ise 28 'dir.

Okuma Motivasyonu Profili-Türkçe Formu, okumanın değeri (9 soru) ve okuyucu benlik algıs1 (9 soru) olmak üzere iki alt ölçekten oluşmaktadır. Ölçekler 4'lü Likert şeklinde derecelendirilmiştir. Okuma Motivasyonu Ölçeği sonucuna göre en düşük 0 puan alınabilecekken en yüksek 72 puan alınabilmektedir (Y1ldı, 2013a).

\section{Kişisel Bilgi Formu:}

Araştırmacı yazından faydalanarak 10 sorudan oluşan bir form hazırlamıştır. Kişisel bilgi formu; öğrencilerin cinsiyet, sınıf seviyesi, ailenin aylık gelir durumunu, eğitim düzeylerini ve mesleklerini, evlerinde internet, kitaplık ve kendilerine ait odası olup olmadığını belirlemeye yönelik sorulardan oluşmaktadır. sunulmuştur.

Bahsedilen veri toplama araçları ile kullanım amaçlarını içeren bilgiler Tablo 2'de 
Tablo 2

\begin{tabular}{|c|c|c|}
\hline $\begin{array}{l}\text { Veri Toplama } \\
\text { Aracı }\end{array}$ & $\begin{array}{l}\text { Veri Toplam Aracinın } \\
\text { Kullanım Amacı }\end{array}$ & $\begin{array}{l}\text { Kime } \\
\text { Uygulanacağı }\end{array}$ \\
\hline Okuduğunu Anlama Testi & Okuduğunu Anlama Başarısını Ölçülmesi & Öğrenci \\
\hline Okuma Motivasyonu Ölçeği & Okuma Motivasyonunun Ölçülmesi & Öğrenci \\
\hline Doğru ve Sessiz Sözcük Okuma & Doğru ve Sessiz Sözcük Okuma & \\
\hline Akıcılığı Testi & Akıcılığı Başarısının Ölçülmesi & Öğrenci \\
\hline
\end{tabular}

\section{Okuduğunu Anlama Testi}

Çalışmada öğrencilerin okuduğunu anlama başarılarını ortaya çıkarmak maksadıyla, Yııldız (2010)'ın Okuduğunu Anlama Testi kullanılmıştır. Test Millî Eğitim Bakanlığ1 Türkçe Ders Kitabı'nda (2005) yer alan Göçmen Kuşlar adlı bilgilendirici metin ve Bayrağımızın Altında adlı öyküleyici metin olmak üzere iki farklı metin türü ve metin türlerine yönelik okuduğunu anlamayla ilgili çoktan seçmeli 28 maddeden oluşturulmuştur. Testteki maddeler Türkçe Ders programlarında yer alan kazanımlardan hareketle oluşturulmuştur. Uygulamaların sonucuna göre ortaya çıkan güvenirlik katsayısı öyküleyici metni anlama testinde 61, bilgilendirici metin testinde 67'dir. Değerler testlerin sonuçlarının güvenilirliğini ortaya koymaktadır.

\section{Okuma Motivasyonu Ölçeği (Okuma Motivasyonu Profili Ölçeği)}

Okuma Motiasyonu Profili Ölçeği okuma motivasyonun kazanılması ve okuma motivasyonunu etkileyen etmenlerin ortaya çıkarılması amacıyla oluşturulan ilk ölçek olarak bilinmektedir. Ölçek, 9'u okuyucu benlik algısı ve 9' u okumanın değerine yönelik olmak üzere 18 sorudan meydana getirilmiş, 4'lü likert şeklinde hazırlanmıştır. Ölçek öğrencilerin okumaya verdiği önem, okuma etkinliklerinde yer alma durumlarını ortaya çıkarmaya yönelik hazırlanmış sorulardan oluşmaktadır. Okuma motivasyonu ölçeği uygulamalarının sonucuna göre ortaya çıkan güvenirlik katsayısı 84 olarak bulunmuştur. Bu değer testin sonuçlarının güvenilirliğini ortaya göstermektedir.

\section{Doğru ve Akıcı Sessiz Sözcük Okuma Testi (DASSOT)}

DASSOT, birinci kartta 110, ikincide 100, üçüncüde ise 90 tane gerçek sözcük ve gerçek sözcüklerden eşit adette türetilerek oluşturulan sahte sözcükler ile üç sayfadan ibarettir. İlk kartta bir heceli kolay kelimeler, ikinci kartta iki heceli kelimeler bulunmaktadır. Son kartta ise üç ve daha fazla heceden oluşan kelimeler vardır. Çetinkaya (2010) hece sayısı artan söcüklerde okuma eyleminin zorlaştığını belirtmiştir. $\mathrm{Bu}$ yüzden okumanın güçleşmesi kartlardaki sözcüklerin hecelerinin çokluğuna bağlıdır. Verilen zaman zarfında öğrencilerden gerçek kelimeleri bularak belirtmeleri istenmektedir. Uygulama yapılmadan öğrencilere bilgilendirilerek gerçek ve sahte kelimelerle alakalı sormak istedikleri yanıtlanmıştır. Sonrasında öğrencilere kartların her birine birer dakikalık zaman tanınarak gerçek kelimeleri bulup belirtmeleri istenmiştir. Testin güvenirlik kat sayısı kartlar için sırasıyla 78,82 ve 75 şeklinde ortaya çıkmıştır. $\mathrm{Bu}$ değerler test sonuçlarının güvenirliğini göstermektedir.

\section{Verilerin Toplanması ve Analizi}

Çalışma neticesinde elde edilen değerler istatistik paket programı kullanılarak incelenmiştir. Çözümleme sonuçlarında ortaya çıkan değerlere göre öğrencilerin doğru ve akıcı sessiz sözcük okuma düzeyinin, okuduğunu anlama becerisi ve okuma motivasyonu ile ilişkisi yorumlanmaya çalışılmıştır.

Araştırma bulgularının analizinde doğru ve akıcı sessiz sözcük okuma düzeyiyle okuduğunu anlama beceri ilişkisi için Speraman Korelasyon Analizi, doğru ve akıcı sessiz sözcük okuma düzeyiyle okuma motivasyonları arasında ilişkiye bakmak için Pearson Moment Çarpım korelasyonu (basit doğrusal korelasyon), puanların normal dağılım koşullarını sağlayıp sağlamadığı incelendiğinde puanların normallik koşullarını sağlamadıklarını ortaya çıkarmak için Kolmogrov-Smirnov testi, cinsiyete göre doğru ve akıcı sessiz sözcük okuma seviyelerinde anlamlı farklılığın olup olmadığını 
ortaya koymak maksadıyla ilişkisiz örneklemler t testi (Independent Samples t Testi), öğrencilerin anne eğitim düzeylerine göre doğru ve akıcı sessiz sözcük okuma puanlarında anlamlı bir fark olup olmadığına dair Kruskal-Wallis Testi verilerin normal dağılım göstermediği için iki grup arasında fark olup olmadığını bulmak amacıyla karşılaştırma testi olan Mann-Whitney U testi, baba eğitim durumuna göre doğru ve akıcı sessiz sözcük okuma düzeylerindeki farkı ortaya çıkarmak amaciyla İlişkisiz Örneklemler için Tek Yönlü Varyans Analizi (Tek Yönlü ANOVA) kullanılmıştır.

\section{Araştırma Etiği}

Araştırmanın uygulanabilmesi için İzmir İl Millî Eğitim Müdürlüğü’nden yazılı onay alınmıştır. Çalışma boyunca etik unsurlara önem verilerek gerekli izinlerin alınmış olup gönüllük ilkelerine hassasiyetle uyulmuştur. Araştırma verileri 2016-2017 eğitim y1lına ait olduğundan etik kurul kararı gerekmemektedir.

\section{Bulgular}

$\mathrm{Bu}$ kısımda araştırma problemleri başlıkları altında yapılan analizlerin sonucunda elde edilen bulgulara yer verilmiştir.

\section{Öğrencilerin Doğru ve Akıcı Sessiz Sözcük Okuma Testi Sonuçları}

Öğrencilerin doğru ve akıcı sessiz sözcük okuma düzeyinin ölçüldüğü testin değerleri Tablo 3'te yer almaktadır.

Tablo 3

Doğru ve Akıcı Sessiz Sözcük Okuma Testi Sonuçları

\begin{tabular}{|c|c|c|c|c|}
\hline Öğrenci Sayısı (N) & En Düşük Puan & En Yüksek Puan & $\begin{array}{l}\text { Aritmetik Ortalama } \\
\qquad(\overline{\mathbf{x}})\end{array}$ & $\begin{array}{l}\text { Standart } \\
\text { Sapma (S) }\end{array}$ \\
\hline Toplam 725 & 3 & 117 & 53.9 & 17.40 \\
\hline
\end{tabular}

Tablo 3’teki veriler 725 öğrencinin doğru ve akıcı sessiz sözcük okuma düzeylerini belirlemek için uygulanan doğru ve akıcı sessiz sözcük okuma ölçeğinden aldığı puanların aritmetik ortalaması olup bu değer 53,90'dır. Bu puanların standart sapması ise 17,40’tır. Sonuçlar öğrencilerin puan değerlerinin birbirine yakın olduğunu göstermektedir.

\section{Öğrencilerin Okuduğunu Anlama Testi Sonuçları}

Öğrencilerin okuduğunu anlama seviyerlerini ortaya çıkarmak amacıyla yapılan testin değerleri Tablo 4'te sunulmuştur.

Tablo 4

Öğrencilerin Okuduğunu Anlama Testi Sonuçları

\begin{tabular}{cclcc}
\hline $\begin{array}{c}\text { Öğrenci Sayısı } \\
(\mathbf{N})\end{array}$ & $\begin{array}{l}\text { En Düşük } \\
\text { Puan }\end{array}$ & $\begin{array}{l}\text { En Yüksek } \\
\text { Puan }\end{array}$ & $\begin{array}{c}\text { Aritmetik Ortalama } \\
(\overline{\mathbf{x}})\end{array}$ & $\begin{array}{l}\text { Standart } \\
\text { Sapma (S) }\end{array}$ \\
\hline Toplam 725 & 2 & 27 & 15 & 5 \\
\hline
\end{tabular}

Tablo 4'te görüldüğü gibi araştırmaya katılan 725 öğrencinin okuduğunu anlama düzeylerini belirlemek için uygulanan okuduğunu anlama ölçeğinden aldığı puanların aritmetik ortalamas $15^{\prime}$ tir. $\mathrm{Bu}$ puanların standart sapmasının 5 değeri öğrencilerin test puanlarının birbirine yakın olduğunu yansitmaktadir.

\section{Öğrencilerin Okuma Motivasyonu Testi Sonuçları}

Öğrencilerin okuduğunu motivasyonlarını ortaya çıkarmak için yapılan testin sonuçlarına dair yapılan tanımlayıcı istatistik değerleri Tablo 5'te sunulmaktadır. 
Tablo 5

Öğrencilerin Okuma Motivasyonu Testi Sonuçları

\begin{tabular}{cllcc}
\hline $\begin{array}{c}\text { Ŏğrenci Sayısı } \\
(\mathbf{N})\end{array}$ & $\begin{array}{l}\text { En Düşük } \\
\text { Puan }\end{array}$ & $\begin{array}{l}\text { En Yüksek } \\
\text { Puan }\end{array}$ & $\begin{array}{c}\text { Aritmetik Ortalama } \\
(\bar{x})\end{array}$ & $\begin{array}{l}\text { Standart } \\
\text { Sapma (S) }\end{array}$ \\
\hline Toplam 725 & 27 & 72 & 58 & 7.40 \\
\hline
\end{tabular}

Tablo 5’te görüldüğü gibi araştırmaya katılan 725 öğrencinin okuma motivasyonu düzeylerini belirlemek için uygulanan okuma motivasyonu ölçeğinden aldığı puanların aritmetik ortalaması 58'dir. Bu puanların standart sapması ise 7,40’tır.

\section{Sınıf Öğrencilerinin, Doğru ve Akıcı Sessiz Sözcük Okuma Düzeyleriyle Okuduğunu Anlama Becerileri İlişskisi}

Öğrencilerinin, doğru ve akıcı sessiz sözcük okuma düzeyleriyle okuduğunu anlama becerileri arasında ilişki olup olmadığına dair yapılan korelasyon analizi bulguları Tablo 6'da sunulmuştur.

Tablo 6

Doğru ve Akıcı Sessiz Sözcük Okuma Düzeyleriyle Okuduğunu Anlama Becerileri Spearman Korelasyon Analizi Sonuçları

\begin{tabular}{lccc}
\hline Değisken & N & Spearman's rho & p \\
\hline DASSOT Sonucu & 725 & .446 & .000 \\
Okuduğunu Anlama Testi Sonucu & & & \\
\hline
\end{tabular}

Öğrencilerin doğru ve akıcı sessiz sözcük okuma düzeyiyle okuduğunu anlama becerilerinin ilişkisinin olup olmadığına dair yapılan Speraman Korelasyon Analizi, doğru ve akıcı sessiz sözcük okumalarıyla okuduğunu anlama başarılarının pozitif yönde, anlamlı düzeyde bir ilişkisinin olduğu sonucunu göstermektedir (Spearman's rho= $0,446, \mathrm{p}<0.01$ ). Bu değerlere göre öğrencilerin okuduğunu anlama becerisi arttıkça doğru ve akıcı sessiz sözcük okuma düzeylerinin de arttığı söylenebilir.

Okuduğunu Anlama Başarı Testi öyküleyici ve bilgilendirici olmak üzere iki adet metin içermektedir. Araştırmanın verilerinden elde edilen bulgular yoluyla öğrencilerin öyküleyici metin anlama düzeyleri ve bilgilendirici metin anlama düzeylerinin doğru ve akıcı sessiz sözcük okuma becerileriyle ilişisini de inceleme firsatı vermiştir.

Öğrencilerinin, doğru ve akıcı sessiz sözcük okuma düzeyleriyle öyküleyici metin anlama becerileri arasında ilişki olup olmadığına dair uygulanan korelasyon analizi değerleri Tablo 7'de bulunmaktadir.

Tablo 7

Öğrencilerin Doğru ve Akıcı Sessiz Sözcük Okuma Düzeyleriyle Öyküleyici Metin Anlama Becerileri Spearman Korelasyon Analizi Sonuçları

\begin{tabular}{|c|c|c|}
\hline Değişken & Spearman's rho & $\mathbf{p}$ \\
\hline DASSOT Sonucu & .412 & .000 \\
\hline Öyküleyici Metin Anlama Testi Sonucu & 725 & \\
\hline
\end{tabular}

Öğrencilerinin, doğru ve akıcı sessiz sözcük okuma düzeyleriyle bilgilendirici metin anlama becerileri arasında ilişki olup olmadığına dair uygulanan korelasyon analizi değerleri Tablo 8'de sunulmuştur.

Tablo 8

Doğru ve Akıcı Sessiz Sözcük Okuma Düzeyleriyle Bilgilendirici Metin Anlama

Becerileri Spearman Korelasyon Analizi Sonuçları

\begin{tabular}{lccc}
\hline Değişken & N & Spearman's rho & p \\
\hline DASSOT Sonucu & & .389 & .000 \\
\hline Bilgilendirici Metin Anlama Testi Sonucu & 725 & & \\
\hline
\end{tabular}


Öğrencilerin öyküleyici ve bilgilendirici metin anlama düzeyleri ile doğru ve akıcı sessiz sözcük okuma düzeylerindeki ilişkiye bakıldığında anlamlılık değeri öğrencilerin öyküleyici metin anlama düzeylerinin doğru ve akıcı sessiz sözcük okuma düzeyleriyle ilişkisinin daha anlamlı olduğunu göstermektedir.

\section{Sınıf Öğrencilerinin, Doğru ve Akıcı Sessiz Sözcük Okuma Düzeyleriyle Okuma Motivasyonları Arasındaki İlişki}

Öğrencilerin doğru ve akıcı sessiz sözcük okuma düzeyiyle okuma motivasyonları arasında anlamlı bir ilişki olup olmadığına ilişkin uygulanan korelasyon analizi değerleri Tablo 9'da mevcuttur. Tablo 9

Doğru ve Akıcı Sessiz Sözcük Okuma Düzeyiyle Okuma Motivasyonu Spearman Korelasyon Analizi Sonuçlart

\begin{tabular}{lccc}
\hline Değişken & N & Spearman's rho & p \\
\hline DASSOT Sonucu & 725 & .295 & .000
\end{tabular}

Öğrencilerin doğru ve akıcı sessiz sözcük okuma düzeyiyle okuma motivasyonu puanları arasında anlamlı ilişkisinin olup olmadığına dair yapılan Speraman Korelasyon Analizi, doğru ve akıcı sessiz sözcük okuma düzeyleriyle okuma motivasyonu başarılarının pozitif doğrultuda ve anlamlı düzeyde ilişkisi olduğunu gösteriyor (Spearman's rho=0,295, p<0.01). Buna göre öğrencilerin okuma motivasyonları arttıkça doğru ve akıcı sessiz sözcük okuma düzeyleri artmaktadır.

Okuma motivasyonu ölçeği okuyucu benlik algısı ve okumaya verilen değer olmak üzere iki boyuttan oluşmaktadır. Araştırmadan elde edilen veriler doğru ve akıcı sessiz sözcük okuma seviyesiyle bu boyutların ayrı ayrı ilişkisinin incelenmesine de olanak sağlamıştır.

Öğrencilerin doğru ve akıcı sessiz sözcük okuma düzeyiyle okuyucu benlik algısı arasında anlamlı bir ilişki olup olmadığına ilişkin yapılan korelasyon incelemesi Tablo 10'da görülmektedir.

Tablo 10

Doğru ve Akıcı Sessiz Sözcük Okuma Düzeyiyle Okuyucu Benlik Algısı Spearman Korelasyon Analizi Sonuçları

\begin{tabular}{llcc}
\hline Değişken & N & Spearman's rho & p \\
\hline DASSOT Sonucu & 725 & .345 & .000 \\
\cline { 1 - 3 } & & & \\
\hline
\end{tabular}

Öğrencilerin doğru ve akıcı sessiz sözcük okuma düzeyiyle okuyucu benlik algısı arasında anlamlı bir ilişki olup olmadığına ilişkin uygulanan korelasyon analizi değerleri Tablo 11'de bulunmaktadir.

Tablo 11

Doğru ve Akıcı Sessiz Sözcük Okuma Düzeyliyle Okumaya Verilen Değer Spearman Korelasyon Analizi Sonuçları

\begin{tabular}{lccc}
\hline Değişken & N & Spearman's rho & p \\
\cline { 1 - 1 } & 725 & .216 & .000 \\
\hline Okumaya Verilen Değer & & & \\
\hline
\end{tabular}

Öğrencilerin okuyucu benlik algıları ve okumaya verilen değer ile doğru ve akıcı sessiz sözcük okuma beceri ilişkisine bakıldığında anlamlılık değerleri öğrencilerin benlik algıları ile doğru ve akıcı sessiz sözcük okuma seviyeleri ile ilişkisinin daha anlamlı olduğunu göstermektedir. 


\section{Sınıf Öğrencilerinin, Doğru ve Akıcı Sessiz Sözcük Okuma Düzeyiyle Türkçe Ders Notu Ortalamaları Arasındaki İlişsi}

4. Sınıf öğrencilerinin, doğru ve akıcı sessiz sözcük okuma düzeyleriyle öğrencilerin Türkçe ders notu ortalamaları arasında ilişkiye yönelik uygulanan korelasyon analizi Tablo 12'de bulunmaktadır.

Tablo 12

Doğru ve Akıcı Sessiz Sözcük Okuma Düzeyiyle Türkçe Ders Notu Ortalamaları Spearman Korelasyon Analizi Sonuçları

\begin{tabular}{lccc}
\hline Değişken & N & Spearman's rho & p \\
\cline { 1 - 2 } & 725 & .477 & .000 \\
\cline { 1 - 4 } & & & \\
\hline
\end{tabular}

Öğrencilerin doğru ve akıcı sessiz sözcük okuma düzeyleriyle Türkçe dersi not ortalamaları arasındaki ilişkinin varlığına dair uygulanan Speraman Korelasyon Analizi doğru ve akıcı sessiz özcük okuma düzeyleriyle Türkçe dersi not ortalamalarının pozitif doğrultuda anlamlı düzeyde ilișkisini göstermektedir (Spearman's rho= 0,477, $\mathrm{p}<0.01$ ). Buna göre öğrencilerin Türkçe ders notu ortalamaları arttıkça doğru ve akıcı sessiz sözcük okuma düzeyleri de artmaktadır.

\section{Cinsiyete Göre Öğrencilerinin Doğru ve Akıcı Sessiz Sözcük Okuma Düzeylerindeki Farklılık}

Cinsiyete göre öğrencilerin doğru ve akıcı sessiz sözcük okuma seviyeleri arasında fark1 belirlemek maksadıyla uygulanan Mann-Whitney U testi değerleri Tablo 13’te verilmişstir.

Tablo 13

Cinsiyete Göre Doğru ve Akıcı Sessiz Sözcük Okuma Düzeyi Farklılık Mann-Whitney U Sonuçları

\begin{tabular}{lccccc}
\hline Grup & $\mathbf{N}$ & $\begin{array}{c}\text { Sira } \\
\text { Ortalaması }\end{array}$ & Sira Toplamı & U & p \\
\hline Erkek & 363 & 353.57 & 128347 & \multirow{2}{*}{62281} & .225 \\
\hline Kız & 362 & 372.45 & 134828 & & \\
\hline
\end{tabular}

Cinsiyete göre doğru ve akıcı sessiz sözcük okuma seviyelerindeki farkı belirlemek maksadıyla uygulanan Mann-Whitney U testi $p$ değeri 0,225 olarak bulunmuştur. Buna göre $p>0,05$ olduğu için grupların puanları arasında fark olmadığı görüldüğü için bu bilgilerden yola çıkılarak cinsiyete göre doğru ve akıcı sessiz sözcük okuma düzeylerinde farklılık olmadığı söylenebilir.

\section{Öğrencilerin Evlerinde İnternet Olması Durumuna Göre Doğru ve Akıcı Sessiz Sözcük Okuma Düzeylerindeki Farklılık}

Öğrencilerin evlerinde internet olması durumuna göre doğru ve akıcı sessiz sözcük okuma seviyelerinde fark bulunup bulunmadığına yönelik uygulanan ilişkisiz örneklemler t testi sonuçları Tablo 14'te bulunmaktadır.

Tablo 14

Doğru ve Akıcı Sessiz Sözcük Okuma Düzeyiyle Internet Arasındaki Anlaml Farklılık T-Testi Sonuçları

\begin{tabular}{lllllllc}
\hline Boyut & Gruplar & $\mathbf{N}$ & $\mathbf{X}$ & $\mathbf{S}$ & Sd & $\mathbf{~ t}$ & $\mathbf{p}$ \\
\hline \multirow{2}{*}{ DASSOT } & Evet & 559 & 55.26 & 17.269 & 723 & 3.807 & .000 \\
\cline { 2 - 5 } & Hayır & 166 & 49.43 & 17.458 & & & \\
\hline
\end{tabular}

Öğrencilerin evlerinde internet olması durumuna göre doğru ve akıcı sessiz sözcük okuma seviyeleri arasındaki farklılığa yönelik yapılan ilişkisiz örneklemler $t$ testinin anlamlılık değeri $\mathrm{p}=0,000$ olarak bulunmuştur. Buna göre $\mathrm{p}<0,05$ olduğundan grupların puanları arasında anlamlı 
farkl111k vardır. Veriler test grubunun evlerinde internet olup olmaması durumlarına göre doğru ve akıcı sessiz sözcük okuma puanları arasında farklılık bulunduğunu göstermektedir. Buna göre evinde internet olan öğrencilerin doğru ve akıcı sessiz sözcük okuma düzeyi daha yüksektir denebilir. Günümüzde e-okuma deneyimlerinin kullanılması, öğrencilerin ödev ve araştırmalarını yapmak için interneti sıklıkla kullanmaları ve internetin öğrencilere çoklu duyusal ortam sağlaması gibi etkenler internetin doğru ve akıcı sessiz sözcük okuma seviyeleri arasında farklılıklar oluşmasına neden olabileceğini göstermektedir.

\section{Öğrencilerin Kendine Ait Odalarının Olup Olmaması Durumuna Göre Doğru ve Akıcı Sessiz Sözcük Okuma Düzeylerindeki Farklılık}

Öğrencilerin kendine ait odalarının olup olmaması durumuna göre doğru ve akıcı sessiz sözcük okuma seviyeleri farklılığını belirlemeye yönelik uygulanan Mann-Whitney U testi değerleri Tablo 15'te sunulmuştur.

Tablo 15

Doğru ve Akıcı Sessiz Sözcük Okuma Düzeyiyle Oda Arasındaki Anlamlı Farklllık Mann-Whitney U Testi Sonuçları

\begin{tabular}{llccccc}
\hline Boyut & Grup & N & Sira Ortalaması & Sira Toplamı & U & p \\
\hline \multirow{2}{*}{ DASSOT } & Evet & 571 & 381.51 & 217843 & & \\
\cline { 2 - 6 } & Hayır & 154 & 294.36 & 45332 & 33397 & .000 \\
\hline
\end{tabular}

Öğrencilerin kendine ait odalarının olup olmaması durumuna göre doğru ve akıcı sessiz sözcük okuma seviyelerindeki farklılığını belirlemeye yönelik uygulanan ilişkisiz örneklemler $t$ testinin anlamlılık değeri $\mathrm{p}=0,000$ olarak bulunmuştur. Buna göre $\mathrm{p}<0,05$ olduğu için grupların puanları arasında anlamlı bir fark vardır. Buna göre öğrencilerin kendilerine ait odasının olup olmamasının doğru ve akıcı sessiz sözcük okuma düzeyi üzerinde anlamlı bir etkisi vardır. Buna kendisine ait odası olanların doğru ve akıcı sessiz sözcük okuma puanları daha yüksektir.

\section{Öğrencilerin Evde Kitaplıklarının Olup Olmaması Durumuna Göre Doğru ve Akıcı Sessiz Sözcük Okuma Düzeylerndeki Farklılık}

Öğrencilerin evde kitaplıklarının olup olmaması durumuna göre doğru ve akıcı sessiz sözcük okuma seviyelerindeki farklılığını belirlemeye yönelik uygulanan Mann-Whitney U Testi değerleri Tablo 16'da sunulmuştur.

Tablo 16

Doğru ve Akıcı Sessiz Sözcük Okuma Düzeyiyle Kitaplık Arasındaki Anlamlı Farklılık Mann-Whitney U Testi Sonuçları

\begin{tabular}{lllllll}
\hline Boyut & Grup & N & Sira Ortalaması & Sira Toplamı & U & p \\
\hline DASSOT & Evet & 560 & 385.31 & 215771 & & \\
\cline { 2 - 6 } & Hayır & 165 & 287.29 & 47403 & 33708.50 & .000 \\
\hline
\end{tabular}

Öğrencilerin evde kitaplıklarının olup olmaması durumuna göre doğru ve akıcı sessiz sözcük okuma seviyeleri farklılığını belirlemeye dair uygulanan ilişkisiz örneklemler $t$ testinin anlamlılık değeri $p=0,000$ olarak bulunmuştur. Buna göre $p<0,05$ olduğundan grupların puan değerleri arasındaki fark anlamlıdır. Bu değerlere göre öğrencilerin evlerinde kitaplık olup olmamasına göre doğru ve akıcı sessiz sözcük okuma seviyeleri farklılaşmaktadır. Evlerinde kitaplık olanların doğru ve akıcı sessiz sözcük okuma puanları daha yüksektir.

\section{Anne Eğitim Düzeyine Göre Öğrencilerin Doğru ve Akıcı Sessiz Sözcük Okuma Düzeylerindeki Farklılık}

Öğrencilerin anne eğitim düzeylerine göre doğru ve akıcı sessiz sözcük okuma puanları arasındaki farklılığını belirlemeye yönelik uygulanan Kruskal-Wallis Testi değerleri Tablo 17'de verilmiştir. 
Tablo 17

Doğru ve Sessiz Sözcük Okuma Akıcılı̆̆ının Anne Eğitim Durumu Değişkenine Göre Farklılaşıp Farklılaşmadığını Belirlemeye Yönelik Kruskal-Wallis Testi Sonuçları

\begin{tabular}{lllllll}
\hline Puan & Gruplar & $\mathbf{N}$ & Sira Ortalaması & sd & $\mathbf{x}^{\mathbf{2}}$ & $\mathbf{p}$ \\
\hline \multirow{5}{*}{ DASSOT } & Okur Yazar & 38 & 154.74 & & & \\
& İlkokul & 262 & 342.62 & & 56.247 & 0.000 \\
\cline { 2 - 5 } & Ortaokul & 156 & 368.05 & & & \\
\cline { 2 - 5 } & Lise & 196 & 396.04 & & & \\
\cline { 2 - 5 } & Üniversite & 73 & 445.05 & & & \\
\hline
\end{tabular}

Tablodan anlaşılacağı gibi öğrencilerin anne eğitim düzeylerine göre doğru ve akıcı sessiz sözcük okuma seviyeleri farklılığını belirlemeye yönelik uygulanan Kruskal-Wallis Testi sonucunda anlamlılık değeri olan $p<0,05$ olduğundan anne eğitim düzeylerine göre doğru ve sessiz sözcük okuma akıcılığı arasında fark olduğu ortaya çıkmıştır. Bu işlemin sonrasında testin sonucunda hangi gruplar arasında farklılık bulunduğunu belirlemek amacıyla çoklu karşılaştırma testi Mann-Whitney U uygun görülmüştür.

Tablo 18

Doğru ve Akıcı Sessiz Sözcük Okuma Düzeyinin Anne Eğitim Düzeyi Değişkenine Göre Farklılaşıp Farklılaşmadığını Belirlemeye İlişkin Kruskal-Wallis Testi ve Mann-Whitney U Testi Sonuçları

\begin{tabular}{|c|c|c|c|c|c|c|c|}
\hline Puan & Gruplar & $\mathbf{N}$ & Sira Ortalaması & sd & $\mathbf{x}^{2}$ & p & Anlamlı Fark \\
\hline \multirow[t]{5}{*}{$\overline{\text { DASSOT }}$} & Okur Yazar & 38 & 154.74 & \multirow{5}{*}{4} & \multirow{5}{*}{56.247} & \multirow{5}{*}{0.000} & \multirow{5}{*}{$\begin{array}{l}2-1,3-1 \\
4-1,5-1 \\
5-2,5-3\end{array}$} \\
\hline & İlkokul & 262 & 342.62 & & & & \\
\hline & Ortaokul & 156 & 368.05 & & & & \\
\hline & Lise & 196 & 396.04 & & & & \\
\hline & Üniversite & 73 & 445.05 & & & & \\
\hline
\end{tabular}

Analizlerin sonucunda farklılığın 2-1, 3-1, 4-1, 5-1, 5-2 ve 5-3 grupları arasında fark olduğunu göstermiştir. $\mathrm{Bu}$ durumda öğrencilerin anne eğitim düzeylerine göre doğru ve akıcı sessiz sözcük okuma puanları arasında fark olup olmadığına dair yapılan Kruskal-Wallis testine göre, grupların doğru ve akıcı sessiz sözcük okuma puanlarında anlamlı fark tespit edilmiştir $(\mathrm{p}<0,05)$. Farklılaşmanın hangi gruplar ile olduğunu bulmak amaciyla Mann-Whitney $U$ testi ile incelenen çoklu karşılaştırmalar sonucunda bu farkın 2-1, 3-1, 4-1, 5-1, 5-2 ve 5-3 grupları arasında olduğu belirlenmiștir.

\section{Öğrencilerin Baba Eğitim Durumuna Göre Doğru ve Akıcı Sessiz Sözcük Okuma Düzeyleri Arasındaki Farklılık}

Öğrencilerin babalarının eğitim durumlarına göre doğru ve akıcı sessiz sözcük okuma puanları arasında fark olup olmadığına dair uygulanan Kruskal-Wallis Testi değerleri Tablo 19'da yer verilmektedir.

Tablo 19

Doğru ve Akıcı Sessiz Sözcük Okuma Düzeyinin Baba Ĕ̆itim Durumu Değişkenine Göre Farklılaşıp Farklılaşmadı̆̆ını Belirlemeye İlişkin Kruskal-Wallis Testi Sonuçları

\begin{tabular}{|c|c|c|c|c|c|c|}
\hline Puan & Gruplar & $\mathbf{N}$ & Sira Ortalaması & sd & $\mathbf{x}^{2}$ & $\mathbf{p}$ \\
\hline \multirow{5}{*}{ DASSOT } & Okur Yazar & 13 & 228.04 & \multirow{5}{*}{4} & \multirow{5}{*}{29.284} & \multirow{5}{*}{0.000} \\
\hline & İlkokul & 208 & 327.35 & & & \\
\hline & Ortaokul & 193 & 341.03 & & & \\
\hline & Lise & 206 & 392.10 & & & \\
\hline & Üniversite & 105 & 431.54 & & & \\
\hline
\end{tabular}

Tablodan anlaşılacağı gibi öğrencilerin baba eğitim düzeylerine göre doğru ve akıcı sessiz sözcük okuma değeri olan $\mathrm{p}<0,05$ olduğundan baba eğitim düzeylerine göre öğrencilerin doğru ve akıcı sessiz sözcük okuma puanları arasında fark olduğu ortaya çıkmışır. Bu işlemin sonrasında testin 
sonucunda bulunan farklılığın hangi gruplar yönünde olduğunu belirlemek amaciyla çoklu karşılaştırma testi Mann-Whitney U uygulanmıştır.

Tablo 20

Doğru ve Akıcı Sessiz Sözcük Okuma Düzeyinin Baba Eğitim Düzeyi Değişkenine Göre Farklılaşıp Farklılaşmadiğını Belirlemeye Illişkin Kruskal-Wallis Testi Ve Mann-Whitney U Testi Sonuçları

\begin{tabular}{|c|c|c|c|c|c|c|c|}
\hline Puan & Gruplar & $\mathbf{N}$ & $\begin{array}{l}\text { Sira } \\
\text { Ortalaması }\end{array}$ & sd & $\mathbf{x}^{2}$ & $\mathbf{p}$ & $\begin{array}{c}\text { Anlamlı } \\
\text { Fark }\end{array}$ \\
\hline \multirow[t]{5}{*}{ DASSOT } & Okur Yazar & 13 & 228.04 & 4 & 29.284 & 0.000 & $4-1,5-1$ \\
\hline & İlkokul & 208 & 327.35 & & & & $4-2,5-2$ \\
\hline & Ortaokul & 193 & 341.03 & & & & $4-3,5-3$ \\
\hline & Lise & 206 & 392.10 & & & & \\
\hline & Üniversite & 105 & 432.75 & & & & \\
\hline
\end{tabular}

Öğrencilerin doğru ve akıcı sessiz sözcük okuma düzeyinin baba eğitim seviyesine göre farklılaşma durumunu belirlemek amaciyla uygulanan Kruskal-Wallis Testi ve Mann-Whitney U Testi değerleri farklılığın 4-1, 5-1, 4-2, 5-2, 4-3 ve 5-3 grupları arasında olduğunu göstermiştir. Bu durumda beş meslek gurubuna göre doğru ve akıcı sessiz sözcük okuma puanları arasındaki farklılığı öğrenmeye yönelik kullanılan Kruskal-Wallis testine göre, grupların doğru ve akıcı sessiz sözcük okuma puanlarında anlamlı fark gözlenmiştir $(\mathrm{p}<0,05)$. Mann-Whitney U testi ile ortaya çıkan çoklu karşılaştırmalar neticesinde farkl1lığın 4-1, 5-1, 4-2, 5-2, 4-3 ve 5-3 grupları arasında olduğu belirlenmiştir. Yani doğru ve akıcı sessiz sözcük okuma seviyeleri baba eğitim durumuna göre farklılaşmaktadır.

\section{Öğrencilerin Annelerinin Mesleklerine Göre Doğru ve Akıcı Sessiz Sözcük Okuma Düzeylerindeki Farklıık}

Öğrencilerin annelerinin mesleklerine göre doğru ve akıc1 sessiz sözcük okuma puanları arasında fark olup olmadığına dair yapılan ilişkisiz örneklemler Tek Yönlü Varyans Analizi değerleri Tablo 21'de yer verilmektedir.

Tablo 21

Anne Mesleklerine Göre Doğru ve Akıcı Sessiz Sözcük Okuma Düzeyinin Karşılaştırılmasına İlişkin Varyans Analizi Sonuçları

\begin{tabular}{|c|c|c|c|c|c|c|c|c|c|c|}
\hline \multicolumn{5}{|c|}{$f, \bar{x}$ ve ss Değerleri } & \multicolumn{6}{|c|}{ ANOVA Sonuçları } \\
\hline Puan & Grup & $\mathbf{N}$ & $\overline{\mathrm{x}}$ & ss & Var. K. & KT. & Sd & KO & $\mathbf{F}$ & $\mathbf{P}$ \\
\hline \multirow[t]{4}{*}{$\overline{\text { DASSOT }}$} & Ev Hanımı & 556 & 54.07 & 17.75 & G.Arası & 344.986 & 3 & 781.662 & \multirow{4}{*}{2.577} & \multirow{4}{*}{053} \\
\hline & Serbest Meslek & 9 & 51.56 & 16.14 & G. İçi & 214700.992 & 721 & 303.330 & & \\
\hline & İşçi & 120 & 51.39 & 16.38 & Toplam & 221045.978 & 724 & & & \\
\hline & Memur & 40 & 60.08 & 15.73 & & & & & & \\
\hline
\end{tabular}

Öğrencilerin annelerinin mesleklerine göre doğru ve akıcı sessiz sözcük okuma puanları arasında fark olup olmadığına ilişkin yapılan varyans analizinin anlamlılık değerine göre $p>0,05$ bulunduğundan grupların ortalamaları arasında anlamlı fark bulunmamıştır. Buna göre doğru ve akıcı sessiz sözcük okuma düzeyi anne mesleklerine göre farklılaşmamaktadır. Yapılan analizler sonucunda doğru ve akıcı sessiz sözcük okuma düzeyi anne mesleklerine göre farklılaşmamaktadır sonucuna ulaşılmasına rağmen annesi memur olanların doğru ve akıcı sessiz sözcük okuma puanlarının diğer meslek gruplarında annesi olan öğrencilerin puanlarına göre daha yüksek olduğunu görülmüştür.

\section{Baba Mesleğine Göre Öğrencilerin Doğru ve Akıcı Sessiz Sözcük Okuma Düzeylerindeki Farklılık}

Baba mesleğine göre doğru ve akıcı sessiz sözcük okuma düzeylerindeki farkın var olup olmadığını ortaya çıkarmak maksadıyla kullanılan Kruskal-Wallis Testi değerlerine Tablo 22'de yer verilmektedir. 
Tablo 22

Doğru ve Akıcı Sessiz Sözcük Okuma Düzeyinin Baba Mesleği Değiş̧kenine Göre Farklılaşıp

Farklılaşmadı̆̆ını Belirlemeye İlişkin Kruskal-Wallis Testi Sonuçları

\begin{tabular}{|c|c|c|c|c|c|c|}
\hline Puan & Gruplar & $\mathbf{N}$ & SiraOrtalaması & sd & $\mathbf{x}^{2}$ & $\mathbf{p}$ \\
\hline \multirow[t]{5}{*}{ DASSOT } & Çalışmıyor & 9 & 288.22 & \multirow{5}{*}{4} & \multirow{5}{*}{16.538} & \multirow{5}{*}{0.002} \\
\hline & Serbest Meslek & 48 & 336.88 & & & \\
\hline & İşçi & 410 & 354.03 & & & \\
\hline & Memur & 82 & 448.40 & & & \\
\hline & Esnaf & 176 & 355.05 & & & \\
\hline
\end{tabular}

Tablodan anlaşılacağı gibi öğrencilerin babalarının mesleklerine göre doğru ve akıcı sessiz sözcük okuma puanları arasında fark olup olmadığına dair yapılan Kruskal-Wallis Testinin anlamlılık değerine göre $p<0,05$ olduğundan grupların puanları arasında fark anlamlı bulunmuştur. Yani öğrencilerin doğru ve akıcı sessiz sözcük okuma düzeyi baba mesleklerine göre farklılaşmaktadır. $\mathrm{Bu}$ işlemin sonrasında testin sonucuna göre hangi gruplar arasında farkın bulunduğunu ortaya çıkarmak amacıyla çoklu karşılaştırma testi Mann-Whitney U uygulanmıştır.

Tablo 23

Doğru ve Akıcı Sessiz Sözcük Okuma Düzeyinin Baba Mesleği Değişkenine Göre Yapılan KruskalWallis Testi Ve Mann-Whitney U Testi Sonuçları

\begin{tabular}{llclcccc}
\hline Puan & Gruplar & $\mathbf{N}$ & $\begin{array}{l}\text { Sıra } \\
\text { Ortalaması }\end{array}$ & sd & $\mathbf{x}^{\mathbf{2}}$ & $\begin{array}{c}\text { p } \\
\text { Anlamlı } \\
\text { Fark }\end{array}$ \\
\hline \multirow{2}{*}{ DASSOT } & Çalışmıyor & 9 & 288.22 & 4 & 16.538 & 0.020 & $4-1$ \\
& Serbest Meslek & 48 & 336.88 & & & $4-2$ \\
& İşçi & 410 & 354.03 & & & $4-3$ \\
& Memur & 82 & 448.40 & & & $5-4$ \\
& Esnaf & 176 & 355.05 & & & \\
\hline
\end{tabular}

Öğrencilerin baba mesleğine göre doğru ve akıcı sessiz sözcük okuma düzeyinin gruplardan hangileri arasında fark bulunup bulunmadığına yönelik uygulanan Mann-Whitney U Testi sonuçları 41, 4-2, 4-3 ve 5-4 grupları arasında fark olduğunu göstermektedir. Yani doğru ve akıcı sessiz sözcük okuma düzeyi akıcılığı baba mesleklerine göre farklılaşmaktadır.

\section{Sonuç, Tartışma ve Öneriler}

Araştırmada öğrencilerin doğru ve akıcı sessiz sözcük okuma seviyeleriyle okuduğunu anlama becerileri arasında anlamlı düzeyde ilişki doğrulanmıştır. Okuduğunu anlama becerisi gelişmiş olanların doğru ve akıcı sessiz okuma seviyeleri de gelişmiştir. Baştuğ ve Akyol (2012) tarafından yapılan, öğrencilerin akıcı okuma becerilerinin okuduğunu anlamayı geliştirme düzeyine ilişkin araştırmaya göre doğru okuma, okuma hızı ve prozodinin birbiriyle ilişkisi belirlenmiş ve bu ilişkinin prozodi becerisi ile okuma hızıyla yakından alakadar olduğu belirtilmiştir. Bu sonuçlardan yola çıkarak söz konusu araştırmaya benzer şekilde öğrencilerin akıcı okuma becerileriyle okuduğunu anlama başarılarının bağlantılı olduğu sonucuna varılmıştır.

Araştırmadan elde edilen bulgulara göre İlkokul 4. Sınıf öğrencilerinin, doğru ve akıcı sessiz sözcük okuma düzeyiyle okuduğunu anlama becerileri arasında anlamlı bir ilişki olduğu bulunmuştur. $\mathrm{Bu}$ doğrultuda öğrencilerin okuduğunu anlama becerisi yükseldikçe doğru ve akıcı sessiz sözcük okuma düzeyinin de arttığı söylenebilir. Bunun yanı sıra testin öyküleyici ve bilgilendirici metinleri ile öğrencilerin doğru ve akıcı sessiz sözcük okuma seviyelerinin ilişkisi incelenmiş, doğru ve akıcı sessiz sözcük okuma seviyeleri ile öyküleyici metinleri anlama düzeyleri arasında bilgilendirici metinleri anlama düzeyleri ile olan ilişkiye oranla daha anlamlı bir ilişki olduğu görülmüştür.

Araştırmanın sonucuna göre öğrencilerin okuma motivasyonları arttıkça doğru ve akıcı sessiz sözcük okuma düzeyleri de artmaktadır. Araştırmada kız öğrencilerin okuma motivasyon ortalamaları erkek öğrencilerden daha yüksek olarak ortaya çıkmıştır. Bu durum alan yazındaki farklı 
araştırmaların sonuçları ile paralellik göstermektedir. Kurnaz ve Yıldız (2015) tarafından gerçekleştirilen çalışmada, okuma motivasyonları yönünden cinsiyetlere göre anlamlı düzeyde bir farklılaşmanın bulunduğu ve farkın kız öğrenciler yönünde olduğu görülmüştür. Benzer şekilde Katrancı (2015) yaptığı araştırma neticesinde kızların erkeklere oranla okuma motivasyonlarının yüksek olduğunu belirlemiştir.

Araştırmanın bir diğer sonucu olarak İlkokul 4. Sınıf öğrencilerinin, doğru ve akıcı sessiz sözcük okuma düzeyiyle okuma motivasyonlarının ilişkisi olduğu sonucuna ulaşı1mıştır. Buna göre öğrencilerin okuma motivasyonları arttıç̧a doğru ve akıc1 sessiz sözcük okuma düzeyleri de artmaktadır. Ayrıca doğru ve akıcı sessiz sözcük okuma seviyesiyle okuyucu benlik algı düzeyleri arasındaki ilişki okumaya verilen değer boyutu ile ilişkisine göre daha yüksek çıkmıștır. Bu durumda okuyucu benlik algısı fazla olanların doğru ve akıcı sessiz sözcük okuma becerilerinin daha iyi olabileceği belirtilebilir.

Yapılan çalışmadan elde edilen veriler neticesinde doğru ve akıcı sessiz sözcük okuma düzeyi ile Türkçe ders notu ortalamaları arasında anlamlı bir ilişkinin olduğu bilgisine ulaşılmıştır. Bu bilgiden yola çıkarak doğru ve akıcı sessiz sözcük okuma başarısı yüksek olan öğrencilerin, Türkçe dersinde de başarılı öğrenciler olduğu da söylenebilir.

Araştırmada, cinsiyet değişkeninin doğru ve akıcı sessiz sözcük okuma düzeyi üzerinde anlamlı farklılık oluşturmadığ görülmüştür. Bu sonuca benzer olarak Saracaloğlu vd. (2011)'nin yaptıkları çalışmada cinsiyetin değişkeninin sekizinci sınıf öğrencilerinin sessiz okuma başarısı için belirleyici olmadığını, oluşan farkın bireysel farklıların bir sonucu olduğunu belirtmişlerdir.

Araştırmaya göre cinsiyetin doğru ve akıcı sessiz sözcük okuma düzeyi üzerinde anlamlı bir etkisinin olmadığı söylenebilir. Buna göre doğru ve akıcı sesiz sözcük okuma düzeyi bakımından kız ve erkek öğrencilerin arasında farklılık mevcut değildir.

Çalışma bulguları öğrencilerin evlerinde internet olup olmamasının doğru ve akıcı sessiz sözcük okuma düzeyi üzerindeki etkisini göstermektedir. Buna göre evinde internet olanların doğru ve akıcı sessiz sözcük okuma başarısı daha yüksektir denebilir.

Araştırma sonucunda öğrencilerin kendilerine ait odasının olup olmamasının doğru ve akıcı sessiz sözcük okuma seviyeleri üzerinde anlamlı etkisinin bulunduğu bilgisi ortaya çıkarılmıştır. Buna göre kendisine ait odası olan öğrencilerin doğru ve akıcı sessiz sözcük okuma puanları daha yüksektir.

Uygulanan ölçeklerin sonuçları değerlendirildiğinde öğrencilerin evlerinde kitaplık olup olmamasının doğru ve akıcı sessiz sözcük okuma düzeyi üzerinde anlamlı bir etkisi vardır ve evlerinde kitaplık olan öğrencilerin puanları daha yüksektir.

Araştırmadan elde edilen bulgulara göre anne eğitim düzeylerine göre öğrencilerin doğru ve akıcı sessiz sözcük okuma düzeyi arasındaki farklılık anlamlı bulunmuştur. Buna göre anne eğitim düzeyi yüksek olan öğrencilerin doğru ve akıcı sessiz sözcük okuma konusunda daha başarılı oldukları söylenebilir. Çalışmanın verileri baba eğitim düzeylerine göre de öğrencilerin doğru ve akıcı sessiz sözcük okuma puanları arasında fark olduğunu göstermiştir. Buna göre baba eğitim düzeyi yüksek olan okuma konusunda daha başarılı oldukları söylenebilir.

Araştırmada anne-baba eğitim düzeyinin doğru ve akıcı sessiz okuma düzeyi üzerinde farklılıklar oluşturduğu sonucuna varılmıştır. Bu durum sebebi olarak eğitim düzeyi yüksek olan anne ve babaların okumaya karşı olumlu tutumlarının öğrencileri de etkilediği ve öğrencilerin bu konuda daha çok teşvik edildiği şeklinde yorumlanabilir. Kurnaz ve Yıldız (2015) tarafindan yapılan araştırmada ebeveynlerin eğitim durumlarının çocukların başarılarındaki önemi ve yine ebeveynlerin evde kitap okumalarının çocuklarının motivasyonlarını arttırdığı belirtilmiştir. 
Yapılan çalışmanın bulgularından yola çıkarak öğrencilerin annelerinin mesleklerine göre doğru ve akıcı sessiz sözcük okuma düzeylerinin karşılaştırılmasında gruplar ortalamaları arasında anlamlı fark bulunamamıştır. Ancak annesi memur olan öğrencilerin doğru ve akıcı sessiz sözcük okuma puanlarının diğer meslek gruplarında annesi olan öğrencilerin puanlarına göre daha yüksek olduğunu görülmüştür.

Araştırmada anne-baba mesleğinin doğru ve akıcı sessiz sözcük okuma düzeyi üzerinde farklılık oluşturup oluşturmadığına bakıldığında anne mesleklerine göre farklılık olmadığı fakat baba mesleklerine göre anlamlı farklılık olduğu sonucuna ulaşı1mıştır. Babası memur ve esnaf olan öğrencilerin gerek doğru ve akıcı sessiz sözcük okuma gerek okuduğunu anlama becerileri ve okuma motivasyonları yüksek çıkmıştır. Meslekler ailenin sosyoekonomik durumunda belirleyici olmaktadır. Çünkü bu ailenin gelir düzeyinin dolayısıyla olanaklarının belirleyicisidir. Bu durumda gelir düzeyinin fazla olduğu ailelerin çocuklarının başarı seviyelerinin de yüksek olduğunu söylemek doğru olacaktır. Araştırma sonucunda baba mesleğine göre de doğru ve akıcı sessiz sözcük okuma seviyelerindeki farklılık anlamlı olarak bulunmuştur. Buna göre özellikle baba eğitim düzeyi memur ve esnaf olanların okuma konusunda daha başarılı oldukları söylenebilir.

Okuduğunu anlama başarısının yüksek olması durumunda doğru ve akıcı sessiz sözcük okuma düzeyinin de yüksek olduğu görülmüştür. Buna göre okuduğunu anlama ile akıcı okuma çalışmaları ilişkisi eğiticiler tarafından önemle dikkate alınarak eğitim öğretim faaliyetleri kapsamındaki çalışmalar bu yönde şekillendirilmelidir, öğrencilerin başarılarını arttırmak için doğru ve akıcı sessiz sözcük okuma becerilerine ağırlık verilmesi ortaya çıkan sonuçlar ile gereklilik olarak görülmelidir, öğrencilerin evlerinde kitaplık olmasının olumlu sonuçları düşünüldüğünde öğretmenler ve veliler öğrencilere evde kitaplık oluşturulması konusunda daha teşvik edici ve destekleyici olmalıdır. Yapılacak araştırmalara yönelik ise farklı sınıf düzeylerinde uygulanarak sonuçlar karşılaştırılabilir, anne baba eğitim düzeyinin etkileri üzerine ebeveynler bilgilendirilerek öğrencilere model olmaları konularında bilgi sahibi olmaları sağlanabilir, konuyla ilgili velilerle çalışmalar yapılarak öğrencilerde olumlu etkilerin oluşması sağlanabilir.

\section{Yazarların Katkı Oranı}

Bu makaleye birinci yazarın \%50, ikinci yazarın $\% 50$ oranında katkısı vardır.

\section{Çıkar Çatışması}

Bu çalışmada çıkar çatışması teşkil edebilecek bir durum yoktur.

\section{Kaynaklar}

Ateş, M. (2008). İlköğretim ikinci kademe öğrencilerinin okuduğunu anlama düzeyleri ile Türkçe dersine karşı tutumları ve akademik başarıları arasındaki ilişsi. Doktora Tezi, Selçuk Üniversitesi Sosyal Bilimler Enstitüsü, Konya.

Aytaş, G. (2005). Okuma eğitimi. Türk Ĕ̌itim Bilimleri Dergisi, 3(4), 461-470.

Baştuğ, M. ve Akyol, H. (2012). Akıcı okuma becerilerinin okuduğunu anlamayı yordama düzeyi. Kuramsal Eğitimbilim Dergisi, 5(4), 394-411.

Çelik, C. E. (2006). Sesli ve sessiz okuma ile içten okumanın karşılaştırılması. D.Ü. Ziya Gökalp Eğitim Fakültesi Dergisi, (7), 18-30.

Çetinkaya, G. (2010). Türkçe metinlerin okunabilirlik düzeylerinin tanımlanması ve sinıflandırllması. (Yayımlanmamış doktora tezi). Ankara Üniversitesi, Sosyal Bilimler Enstitüsü, Ankara. 
Çetinkaya, G. Ülper, H. ve Yağmur, K. (2015). Öğrencilerin doğru ve akıcı sessiz sözcük okuma becerileriyle kavrama başarıları arasındaki ilişki. İlköğretim Online, 14(3), 993-1004. http://ilkogretim-online.org.tr.

Ertuğrul, H. (2015). Illk ve ortaöğretimde öğrencinin başarı kılavuzu. İstanbul: Nesil Basım Yayın.

Gambrell, L. B. (2011). Motivation in school reading curriculum. Journal of Reading Education, $37(1), 5-14$.

Güneş, F. (2007). Ses temelli cümle yöntemi ve zihinsel yapılandırma. İstanbul: Nobel Yayınları.

Karasar, N. (2011). Bilimsel araştırma yöntemi. Ankara: Nobel Yayınevi.

Katrancı, M. (2015). İlkokul dördüncü sınıf öğrencilerinin yazma ve kitap okuma motivasyonlarının incelenmesi. Ana Dili Eğitimi Dergisi, 3(2), 49-62.

Kuhn, M. R., Schwanenflugel, P. J. and Meisinger, E. B. (2010). Aligning theory and assessment of reading fluency: Automaticity, prosody, and definitions of fluency. Reading Research Quarterly, 45, 230-251.

Kurnaz, H. ve Yıldız, N. (2015). Ortaokul öğrencilerinin okuma motivasyonlarının çeşitli değişkenlere göre değerlendirilmesi. Türkiye Sosyal Araştırmalar Dergisi, 19 (3),53-70.

Milli Eğitim Bakanlığı. (2015). Türkçe dersi (1-8. Sinıflar) öğretim programı. Talim ve Terbiye Kurulu Başkanlığı Ankara.

Oakhill, J., Cain, K. and Elbro, C. (2014). Understanding and teaching reading comprehension: A handbook. Routledge. doi: 10.4324/9781315756042.

Saracaloğlu, A. S., Dedebali, N. C. ve Karasakaloğlu, N. (2011). Sekizinci sınıf öğrencilerinin sessiz okuma hızları ve okuduğunu anlama düzeyleri. Ahi Evran Üniversitesi Eğitim Fakültesi Dergisi, 12 (3), 177-193.

Ülper H. ve Yağmur, K. (2016). Akıcı sessiz sözcük okuma testinin geliştirilmesi. İlköğretim Online, 15(2), 581-593. http://dx.doi.org/10.17051/io.2016.91112.

Yildı, M. (2013a). Adaptation of the motivation to read profile to Turkish. International Journal of Academic Research, 5(4), 196-199.

Yıldız, M. (2013b). Okuma motivasyonu, akıcı okuma ve okuduğunu anlamanın beşinci sınıf öğrencilerinin akademik başarılarındaki rolü. International Periodical For The Languages, Literature and History of Turkish or Turkic, 8(4), 1461-1478.

Yılmaz, M. (2011). İlköğretim 4. Sınıf öğrencilerinin okuduğunu anlama seviyeleri ile Türkçe, matematik, sosyal bilgiler ve fen ve teknoloji derslerindeki başarıları arasındaki ilişkinin belirlenmesi. Dumlupınar Üniversitesi Sosyal Bilimler Dergisi. 29, 9-14. 


\section{Extended Abstract}

\section{Introduction}

Turkish language teaching is based on teaching of listening, speaking, reading and writing skills. Among these skills, the importance of reading never lost its reputation. Learning how to read during primary school years lead not only various academic improvements but also lead social changes in human life. Comprehension of reading and fluent reading are crucial issues after learning the ability of how to read. Fluent reading is defined as reaching to a certain level. Researchers stated that students who can read fluently and comprehend the text appropriately are not only successful in Turkish lesson but also they are found to be successful in other subjects. (Yildız, 2013; Ateş, 2008; Yılmaz, 2011; Çetinkaya, Ülper ve Yağmur, 2015).

Individuals mostly spare time on silent reading among other reading methods. Silent reading facilitates faster reading and encourages the comprehension. Silent reading facilitates comprehension of reading abilities and also improves students' cognitive development. Çelik (2006, s.25) defined the process from reading aloud to silent reading. He stated that after learning how to read and write, students begin to gain the habit of silent reading while approaching to second grade. After this period he adviced to practice silent reading activities.

It is obvious that careful attention should be given to silent reading. Researches about reading styles are mostly investigate the fluency of reading aloud. This research will contribute to the literature by investigating the fluency of silent reading. Lack of studies in this area indicates the need for more research. For this reason, in this study the relationship between fourth grade students' accurate and fluent silent word reading level with students' comprehension abilities and reading motivation were investigated.

\section{Method}

The aim of the study was to investigate the relationship of fourth grade students' accurate and fluent silent word reading level with their comprehension ability and their reading motivation. The students were attending a state school in İzmir, Buca in 2016-2017 academic year. Relational scanning model was used. Relational models were used in many studies in order to determine two or more variables simultaneous change (Karasar, 2011).

The scope of this study comprises primary school fourth graders who were attending a state school in İzmir, Buca. For samples 34 primary school students were recruited. With randomized sample method, only one fourth grade class was chosen in every primary school and the study group comprised of 725 students.

To investigate students' comprehension level, Comprehension Test (Yıldız, 2010); to investigate the students' motivation, Reading Motivation Scale (Yıldız, 2010) and to investigate students' fluent silent word reading ability Ülper and Yağmur's Correct and Fluent Silent Word Reading Test (DASSOT) were used. All the data were evaluated by SPSS program.

\section{Results, Discussion and Conclusion}

The results of this study approved that there is a positive correlation between the students' accurate and fluent silent reading level with their comprehension abilities. The students' who have advanced comprehension skills also have improved accurate and fluent silent reading abilities. The results of the study showed that there is a significant correlation between accurate and fluent reading level and the comprehension of narrative texts rather than informative texts.

The results of the study also suggest that the accurate and fluent silent reading performance increases as the reading motivation increases. Mean reading motivation scores of female students were higher than that of male students. This finding is in consistence with the previous literature. Kurnaz and Yildiz (2015) suggested that there was gender difference in reading motivation in favor of female students. Similarly, Katranci (2015) also stated that female students had higher reading motivation compared to male students. 
Another finding of the study is that students' accurate and fluent silent reading level and their reading motivation is correlated. What is more, the accurate and fluent silent reading levels are more strongly correlated with reader self-conciousness levels. Thus one may easily suggest that higher selfconciousness level comes with better accurate and fluent silent reading skills.

The results also show that accurate and fluent silent reading levels are correlated with Turkish course grades; suggesting that students with better accurate and fluent silent reading skills are more successful in Turkish courses.

The study also revealed that gender had no relation with accurate and fluent silent reading levels. Likewise, Saracaloglu et al (2011) also suggested that gender had no influence on 8th grade students' silent reading skills and the somehow the difference was found to be related with personal differences.

This study has revealed that internet service availability has positive effect on students' accurate and fluent silent reading skills. The presence of a self-occupied room also had a positive effect on accurate and fluent silent reading level of the students. The presence of a bookshelf at home had a positive effect on accurate and fluent silent reading level of students.

The results of study revealed that maternal education level categories showed significant difference in accurate and fluent silent reading levels. Higher maternal education levels had positive effect on accurate and fluent silent reading levels.

The results of the study suggests that there is a significant difference in students' silent word reading scores among fathers' education levels. Thus students whose fathers' education level were high performed better in accurate and fluent silent word reading.

The study suggested that parental education levels have an effect on accurate and fluent silent reading performance. The rationale for this phenomenon seems to be positive attitude towards reading. Likewise, Kurnaz and Yildiz (2015) suggested that parental education levels had positive effects on students' educational performances and parents' reading activities increased motivations of children.

On the other hand, the results of the study failed to show significant difference in accurate and fluent silent reading abilities with maternal occupation categories. Whereas, scores of students whose mothers were governmental office workers had higher scores with respect to others.

The results revealed that when groups were compared according to their parental occupational, there was no significant difference on accurate and fluent silent reading abilities among groups. On the other hand, fathers' occupational category had effects on accurate and fluent silent reading. Children whose fathers were govenrmental office workers and retailers had not only higher scores in accurate and fluent silent reading scores but also had better reading comprehension and reading motivation as well. Occupational status has definitive influences on socioeconomical status of families. Family income also detemines facilities and opportunities available. The higher the family income levels are the higher the children's performance are.

The results of the study revealed that students who have higher reading comprehension scores also have higher accurate and fluent silent reading performances. Future studies should be planned considering this relation.

The results of the study revealed that 4 th grade students accurate and fluent silent reading scores and Turkish course scores are correlated. According to this finding in order to increase the course success, accurate and fluent silent reading performance should be encouraged. Further studies should be performed and the results can be compared in different grades. Regarding the positive effects of having a bookshelf at home, foundation of a basic bookshelf should be promoted. Parental motivation and counseling should be provided to facilitate higher student performances. 